\title{
A ressurreição de Jesus a partir do pensamento de Andrés Torres \\ Queiruga
}

Orientador: Prof. Paulo Cezar Costa

Mestrando: Marcelo Batalioto

Área de Concetração: Teologia Sistemático-Pastoral

Linha de Pesquisa: Fé e Cultura

O tema da Ressurreição de Jesus é repensado pelo teólogo Andrés Torres Queiruga, com o intuído de evidenciar o seu significado dentro do atual contexto teológico. Uma releitura profunda e equilibrada dos textos bíblicos, principalmente das narrativas do sepulcro vazio e das aparições, permite constatar a ausência da provas históricas da ressurreição de Jesus. Esses textos são, principalmente, construções teológicas que buscam interpretar o sentido do evento da ressurreição numa comunidade de fé. Num caminho de síntese, Queiruga busca encontrar o equilíbrio na reflexão bastante intrincada sobre o Jesus histórico. Em consonância com autores relevantes da cristologia recente, ele critica o otimismo da teologia liberal, que acreditava ser possível chegar até o Jesus da história. Da mesma forma são criticadas as pretensões da teologia querigmática, sintetizada no pensamento de Rudolf Bultmann, que dispensava a história de Jesus para a formulação do querigma. Embora a ressurreição de Jesus não seja um evento constatável em si mesmo, no sentido empírico do termo, dentro da história, é certo que se trata de um acontecimento, realizado pela iniciativa de Deus, que atinge e marca a história. É nesse sentido que Queiruga, amparado por outras reflexões cristológicas, entende a ressurreição de Jesus. 